\title{
Orta Eğitim Kademesindeki Öğretmen ve Öğrencilerin Şiddet Algılarının Kırsaldaki Görünürlüğü
}

\section{Rural Visibility of Teachers and Students of Violence of Secondary Education Levels}

\author{
Gönül ŞENER ${ }^{*}$
}

Received: 29 October 2018

Research Article

Accepted: 29 July 2019

\begin{abstract}
In recent years, with the increase in the visibility level in our country, it is obligatory to talk, think and research on the violent events which are especially alarming in schools. With research in this direction, violence perceptions of the teachers working in primary and secondary schools in rural areas and students in these schools were tried to be determined through metaphors. In this context, students were asked to fill empty questionnaires of the participants by giving blank questionnaires including "Violence ............", "Because ........". The study group of the study consisted of the sixth, seventh and eighth grade students who were educated in the Palu district of Elazığ province and the teachers working in these schools. The research is based on qualitative research methods. Metaphor was used as data collection tool. The analysis of the data was conducted within the context of content analysis. The responses of students and teachers to the semi-structured form were examined and a metaforest list was created. The resolutions were made on this list. As a result of the research; it was seen that opinions on student perceptions were collected more aggressively on the themes of aggressive human, fear and intimidation while the views on addictive habitual contact were less repeated. Opinions on teacher perceptions were more aggressive in terms of people, natural disasters and disappearances, while opinions on the theme of abuse and insult were less frequent.
\end{abstract}

Keywords: student, violence, teacher, rural.

ÖZ: Son yıllarda ülkemizde görünürlük düzeyinde meydana gelen artışla birlikte özellikle okullarda kaygı verici bir hal alan şiddet olayları üzerinde konuşmayı, düşünmeyi, araştırmayı zorunlu kılmaktadır. Bu doğrultuda yapılan araştırma ile kırsal alanda yer alan orta eğitim kademesinde görev yapan öğretmenler ile bu okullarda öğrenim gören öğrencilerin şiddet algıları metaforlar aracılığıyla belirlenmeye çalışılmıştır. $\mathrm{Bu}$ bağlamda öğrencilere "Şiddet.............gibidir" "Çünkü............." ifadelerini içeren boş soru formları verilerek, katılımcıların boş soru formlarını doldurmaları istenmiştir. Araştırmanın çalışma grubunu Elazı̆̆ ili Palu ilçesinde öğrenim gören altı, yedi ve sekizinci sınıf öğrencileri ile bu okullarda görev yapan öğretmenler oluşturmaktadır. Araştırma, nitel araştırma yöntemlerinden olgubilim deseni kullanılmıştır. Veri toplama aracı olarak metafor kullanılmıştır. Verilerin analizi ise içerik analizi çerçevesinde yürütülmüştür. Öğrencilerin ve öğretmenlerin yarı yapılandırılmış forma verdikleri cevaplar incelenmiş ve metafor listesi oluşturulmuştur. Çözümlemeler bu liste üzerinden yapılmıştır. Araştırma sonucunda; öğrenci algılarına ilişkin görüşlerin daha çok saldırgan insan, korku ve zor kullanma temalarında toplandı ̆̆ı, buna karşın, bağımlılık yaratan alışkanlık temasına ilişkin görüşlerin daha az tekrarlandığı görülmüştür. Öğretmen algılarına ilişkin görüşlerin ise daha çok saldırgan insan, doğal afet ve kayboluş temalarında toplandığı, zor kullanma ve hakaret temasına ilişkin görüşlerin ise daha az tekrarlandığ 1 görülmüştür.

Anahtar kelimeler: öğrenci, şiddet, öğretmen, kırsal.

\footnotetext{
* Corresponding Author: Asst. Prof. Dr., Munzur University, Tunceli, Turkey, gonulsener@munzur.edu.tr, https://orcid.org/0000-0003-3212-7703
}

Citation Information

Şener, G. (2019). Orta eğitim kademesindeki öğretmen ve öğrencilerin şiddet algılarının kırsaldaki görünürlüğü, Kuramsal Eğitimbilim Dergisi [Journal of Theoretical Educational Science], 12(3), 1124-1141. 


\section{Giriş}

Ülkemizde son yıllarda görünürlük düzeyinin yaygınlaşmasına paralel olarak eğitim kurumlarındaki şiddet olgusunun gün geçtikçe kaygı verici bir hal aldığı ileri sürülmektedir (Kızmaz, 2006, s. 47). Son dönemlerde, okullarda artan bu şiddet olgusu, toplumu rahatsız etmekte ve şiddet üzerinde düşünmeye, konuşmaya, bilimsel araştırma yapmaya yöneltmektedir. Kendini çok değişik biçimlerde ortaya koyan şiddet olgusu, günümüzde hem bireysel hem de toplumsal boyutta sık sık karşı karşıya kalabildiğimiz bir olgu durumuna gelmiştir.

Yaşantımızın hemen her alanında, herkesi etkisi altına alabilen ve insan doğasında bastırılmış bir davranış biçimi olarak bilinen şiddet (Mutlu, 1997), bireylere ve topluma zarar verebilecek tüm eylemleri kapsamaktadır. Şiddetin oluşumu, bireyin bilinçaltına, dürtülerine, yaşadığı sosyo-kültürel ve sosyo-ekonomik koşullarına bağlı olarak açıklanabilmektedir (Kale, 2004, s. 42). Şiddet, kişinin fiziksel ve psikolojik bütünlüğünü tehdit eden her türlü maddi ve manevi olumsuzluk olarak tanımlanmaktadır (Ayan, 2007, s. 207). Diğer bir tanımda ise şiddet, herhangi bir kişiye ve onun eşyalarına kasıtlı olarak yapılan istenmeyen durumların o kişi üzerinde, fiziksel, duygusal ya da psikolojik yönüyle yarattığı acıdır (Çınkır, 2006, s. 1).

Saldırganlığın davranışa yansımış hali olarak ifade edilen şiddet, bir kimsenin fiziksel güç ya da herhangi bir nesne kullanarak, diğer kimseyi yaralaması ya da ona zarar vermesi olarak bilinmektedir. Aslında şiddeti bir saldırganlık biçimi olarak söylemek yanlış olmayacaktır. En temel fark şiddetin "fíziksel gücün kullanımına" dayalı olmasidir (Olweus, 1999).

Şiddet bütün insanlık için olumsuz bir durum olarak bilinirken bu durum çocuklar için daha yıkıcı bir hal almaktadır. Günlük yaşamda sıkça karşılaştığımız şiddetin kökeni ve nedenleri hakkında çok sayıda çalışma yapılmış ve birçok kuram geliştirilmiştir. Araştırmacılar şiddetin nedenini en köklü ve en iyi şekilde belgeleyen kuramın Bandura'nın sosyal öğrenme kuramı olduğu sonucuna ulaşmıştır (Küçükturan \& Akbaba Altun, 2006, s. 95). Kurama göre; aile içi şiddete maruz kalan çocuk şiddet davranışını öğrenmekte ve içselleştirmektedir (Bandura, 1978; Çetiner, 2006, s. 23). Çocuklar şiddet olgusu ile önce ailede tanışmaktadır (Kale, 2004, s. 42). Yapılan araştırmalar, okullarda yaşanan şiddet olaylarının temeli olarak çocukluk dönemindeki şiddet davranışları araştırılmakta, şiddetin bireyin gelişiminin doğal bir parçası olmadığı sonucuna ulaşılmaktadır (Totan, 2007, s. 191). Bu nedenle, çocuklarının ruhsal, sosyal ve fiziksel gereksinimlerini öncelikle anne ve babaların dikkate almaları gerekmektedir (Usta, 2009, s. 103). Çünkü çocuk, okula geldiğinde aileden getirdiği özellikleriyle okuldaki bütün iletişim ve etkileşim etkinliklerini gerçekleştirmektedir (Uysal, 2003, s. 30). İkinci sosyalleşme kurumu olan okulun çocuk hayatındaki yeri tartışılmaz olmakla birlikte, evde başlayan şiddetin okulda devam ettiği bilinmektedir (Gamsız Bilgin, Toros, Çamdeviren, \& Şaşmaz, 2004, s. 25).

Yapılan araştırmalar okullarda yaşanan şiddet durumlarının artmasının nedenleri olarak; öğretmen-öğrenci ilişkilerindeki zayıflık, öğretmenin öğrencilere olan ilgisizliği ve okul organizasyonunun zayıflığ1 gibi değişkenler gösterilmektedir (Özönder, 2005, s. 10). $\mathrm{Bu}$ nedenler 1şı̆̆ında okullarda yaşanan şiddet durumlarına ilişkin kaygı giderek artış gösteren bir hal almaya başlamıştır (Işı1k, 2006, s. 74). 
Toplum içinde şiddetin nasıl kabul gördüğü ve nasıl sunulduğu da önem taşımaktadır. Şiddet yaşamın bir parçası olarak benimseniyorsa sorun olarak karşılanmaz ve sorun çözmenin haklı bir aracı olarak meşru kabul edilir (Yatmaz, 2009, s. 23). Şiddet olgusu kültür temelinde ele aldığında özellikle yaşadığımız coğrafyada dayak atmak ve dayak yemek yüzyıllardır normal bir davranış olarak algılanmıştır. Bu olgu, birçoğumuzu okulda, birçoğumuzu ise evde ve sokakta yakalamıştır. Özellikle kırsal alanda yaşayan insanların kültürel, ekonomik ve eğitimsel açıdan eksik yanlarının olduğu bilinen bir gerçektir. Palu ilçesi de diğer kırsallarda olduğu gibi bu eksikliklerin yaşandığı bir bölgedir. Sosyal ve ekonomik açıdan gelişmemiş bir coğrafyada bulunan Palu'da sosyo-kültürel yaşam ve eğitim de bu durumdan olumsuz etkilenmektedir. $\mathrm{Bu}$ bölgede yaşayan aileler çocuklarının eğitiminden çok onların temel ihtiyaçlarını karşılamak için çalışmaktadırlar (Bakıcı, 2012).

Okullarda yaşanan şiddet olayları hem okulların amacı olan eğitim-öğretim etkinliğini hem de kişinin psikolojik sağlığını olumsuz olarak etkileyebilmektedir. (Terzi, 2007, s. 76). Okullarda şiddetin azaltılması ve önlenmesi amacı ile yapılacak çalışmalarda çocukla ilgili herkesin ve ilgili kurumların işbirliği içinde çalışması önemli bir husustur (Mertoğlu, 2008, s. 28) Okullarda, şiddet olaylarına genellikle ortaya çıktıktan sonra müdahale edilmektedir. Oysa olaylar meydana gelmeden önce, önleyici girişimler oluşturmak daha uygun olacaktır (Taktak, 2007, s. 42). Önleyici girişimler belirlenirken öncelikle şiddeti oluşturan ya da tetikleyen biyolojik, toplumsal, şiddeti bir eğitim aracı olarak kullanma, öğrenme ve kişiler arası etkileşimle ilgili nedenlerin ele alınması Şiddet kısa dönemde okul ikliminin bozulmasına ve okul güvenliğinin zarar görmesine yol açarken, uzun dönemde öğrencilerin okuldan uzaklaşmasına, psikososyal uyumun bozulmasına, suç davranışlarına ve kurbanlarda kaygı, yalnızlık, depresyon gibi olumsuz durumlara yol açabilmektedir (Kartal, 2009, s. 145). Bu nedenle okullarda yaşanan şiddet olayları konusunda, neyin şiddet sayılıp sayılmayacağı yani "şiddet algısı" önemlidir. Bazı öğrenciler/ öğretmenler, belirli tutum ve davranışı şiddet olarak görüp onunla mücadele ederken, bazıları ise aynı tutum ve davranışları şiddet olarak görmemekte, normal bir durum olarak değerlendirmektedir. Kısacası şiddet olarak kabul edilen davranış, öğrencilerin/ öğretmenlerin, inanç ve kültürel yapılarına, değer yargılarına ve kişilik özelliklerine göre farklılık gösterebilmektedir. Okullarda görülen şiddet olaylarında öğretmen ve öğrencilerin algılarının eğitim sisteminde niteliği önemli bir şekilde etkilediği dikkate alındığında; öğretmen ve öğrencilerin bu kavramına ilişkin algılarının ortaya konulması, günden geçtikçe artan şiddet olaylarının önlenebilmesi ve eğitsel tedbirlerin alınabilmesi açısından önemli görülmektedir. $\mathrm{Bu}$ doğrultuda bu araştırmayla ulaşılacak sonuçların konunun anlaşılmasına ve hazırlanacak müdahale programlarına katkı sağlayacağı umulmaktadır. Bu çalışmada günümüzde artık kaçınılmaz hale gelen şiddet olgusunun kırsal alanda yer alan okullardaki görünümü ortaya çıkarılmaya çalışılmıştır. $\mathrm{Bu}$ amaçla aşağıdaki sorulara cevap aranmıştır:

1. Ortaokullarda öğrenim gören altı, yedi ve sekizinci sınıf öğrencileri ile bu okullarda görev yapan öğretmenlerin şiddete ilişkin öne sürdükleri metaforlar nelerdir?

2. Ortaokullarda öğrenim gören altı, yedi ve sekizinci sınıf öğrencileri ile bu okullarda görev yapan öğretmenlerin şiddete ilişkin öne sürdükleri metaforlar hangi kavramsal kategoriler etrafında toplanmaktadır? 
3. Öğrencilerin ve öğretmenlerin öne sürdüğ̈̈ metaforların frekans dağılımları nasildir?

\section{Yöntem}

$\mathrm{Bu}$ araştırmada, nitel paradigma içerisinde değerlendirilen olgubilim "fenomenoloji” deseni ile şekillendirilmiştir. Olgubilim deseni, görebildiğimiz ancak derinlemesine ve ayrıntılı bir anlayışa sahip olmadığımız olgular üzerinde düşünmemizi sağlar. Olgubilim farkında olduğumuz ancak tam olarak anlamını kavrayamadığımız olguları araştırmamıza yardımcı olur (Yıldırım \& Şimşek, 2011).

\section{Çalışma Grubu}

Araştırmanın çalışma evrenini Elazığ iline bağlı Palu ilçesinde yer alan ortaokullar oluşturmaktadır. Araştırmanın örneklemini ise Palu ilçesinden tesadüfî olarak seçilmiş beş ortaokul oluşturmaktadır. Bu okulların üçü ilçe merkezinde yer alırken, ikisi köy okullarından oluşmaktadır. Araştırma kapsamında yer alan öğretmen ve öğrencilerin demografik özelliklerine ilişkin dağılımlar Tablo 1'de görülmektedir.

Tablo 1

Katılımcılara İlişkin Demografik Özellikler

\begin{tabular}{llll}
\hline Katılımcı Türü & $n$ & Özellik & $n$ \\
\hline \multirow{2}{*}{ Öğrenci } & \multirow{2}{*}{166} & Erkek & 85 \\
& & Kadın & 81 \\
\hline \multirow{2}{*}{ Öğretmen } & \multirow{2}{*}{50} & Erkek & 27 \\
& & Kadın & 23 \\
\hline
\end{tabular}

\section{Verilerin Toplanması}

Araştırma verileri metaforlar aracılığı ile toplanmıştır. Zihinsel algıları ifade etmenin yollarından biri de "metaforlardır" (Yalçın \& Erginer, 2012). Metaforlar analiz edilmek istenen kavramların nasıl algılandığını ortaya çıkarmaya çalışır (Cerit, 2008). Arnett (1999) metaforların "bir alg1 aracı" olabileceğini ifade etmiştir. Metafor bireylerin hayal gücü ve tecrübe alanlarını birbirine bağlamakla kalmaz aynı zamanda gerçek algılarımıza ve yorumlarımıza önderlik eder. Ayrıca hayal gücümüzü ve hedeflerimizi kesin olarak belirtmemize yardımcı olur (Cornelissen, Oswick, Christenses, \& Phillips, 2008; Lopez, 2007). Metaforlar, insanın zihninin bir kavrayış formundan başka bir kavrayış formuna hareket etmesine olanak sağlayarak, bireyin belli bir olguyu başka bir olgu ile ilişkilendirmesine olanak tanır (Clarken, 1997; Girmen, 2007; Saban, Koçbeker, \& Saban, 2006). Bu doğrultuda öğrencilerin ve öğretmenlerin şiddet olgusuna yönelik algılarını ortaya çıkarmak amacıyla, tüm katılımcılara "Şiddet.............gibidir” "Çünkü............" cümlesi verilerek tamamlanması istenmiştir. Katılımcılara gerekli açıklama yapılmış, öğretmen ve öğrencilerin soru formunu doldurmaları ve bir sonraki ders saatinde teslim etmeleri istenmiştir. Bu çalışmada "çünkü" kavramına da yer verilerek, katılımcıların şiddet algılarını belirtmede kullandıkları metafor için açıklayıcı bir gerekçe sunmaları amaçlanmıştır. 
Tüm katılımcılar tarafından doldurulan bu form, araştırmanın temel veri kaynağ 1 olarak kabul edilmiştir.

\section{Verilerin Analizi ve Yorumlanması}

Öğretmen ve öğrencilerin görüşlerinden yola çıkarak elde edilen verilerin çözümlenmesinde nitel araştırmaların analizinde kullanılan "içerik analizi" yöntemi kullanılmıştır. Çalışmada ilk olarak öğretmenlerin ve öğrencilerin doldurdukları görüşme formları incelenmiş ve bu formlar üzerinde çözümlemeler yapılmıştır. Herhangi bir metafor kavramını kullanmayan, şiddet hakkında genel görüşlerini belirten katılımcıların soru formları (66) ayıklanmıştır. Bu işlemin ardından araştırmaya katılan 227 öğrenciden 166'sının ve 55 öğretmenden 50'sinin görüşleri geçerli kabul edilmiştir. Öğretmen ve öğrenciler için oluşturulan soru formlarının her birine sayı numarası verilerek elektronik ortama aktarımı sağlanmış ve yanıtlar istatistiksel veri analiz programında analiz edilmiştir.

Araştırmanın güvenirliliğini test edebilmek için, öğretmen ve öğrencilerden elde edilen 216 metaforun, içinde yer aldığı temaya uygun olup olmadığını belirlemek amaciyla uzman görüşüne sunulmuştur. $\mathrm{Bu}$ amaç doğrultusunda, uzman tarafindan oluşturulan tema listesi ve metaforlar ile araştırmacı tarafından oluşturulan tema listesi ve metaforların eşleştirmesi yapılmıştır. Araştırmanın güvenirliğini sağlamak için Miles \& Heberman'ın (1994) geliştirdiği aşağıdaki formül kullanılmıştır:

$$
\text { Uzlaşma Yüzdesi }=\frac{\text { Görüş Birliği }}{\text { Görüş Birliği }+ \text { Görüş Ayrılığ }} \times 100
$$

Nitel araştırmalarda, uzman ve araştırmacı görüşleri arasındaki uyumun $\% 90$ ve üzeri olması araştırmada güvenirliğin sağlandığı anlamına gelmektedir. Bu kapsamda görüşüne başvurulan uzman 15 metaforu araştırmacılardan farklı bir kategoriye yerleştirmiştir. Araştırma verilerinin yukarıdaki formülle analizi sonucunda güvenirlik değeri $\mathrm{P}=216 /(216+15) \mathrm{X} 100=\% 93.5$ olarak bulunmuştur.

\section{Bulgular}

Kırsalda yer alan ortaokullarda öğrenim gören öğrenciler ile bu okullarda görev yapan öğretmenlerin şiddet algılarının metaforlar aracılığı ile belirlenmeye çalışıldığ çalışmanın bu bölümünde öğrencilerin ve öğretmenlerin ileri sürmüş oldukları metaforlar ile oluşturulan temalara yer verilmiştir. İlk olarak öğrencilere verilen soru formlarından elde edilen metaforlar frekanslarıyla birlikte Tablo 2'de listelenmiştir. 
Tablo 2

Ö̆grenciler Tarafından İleri Sürülen Metaforların Temalara Göre Dă̆ılımı

$\begin{array}{ccc}\text { Temalar } & \text { Metaforlar } & f \\ (n=9) & f & (n=85)\end{array}$

\begin{tabular}{ll}
\hline & Azarlamak 1, Bă̆ırıp çă̆ırmak 3, Bilinçsiz insanın \\
& yöntemi 1, Birini dövmek hayata küstürmek 1, Dayak \\
& 33, Insanın elinden çıkan kaza 1, Insanları \\
& cezalandırmak 1, Insanlara zarar vermek 1, İskence \\
Saldırgan İnsan & 1, Kavga 2, Kizgın bir insan 2, Kızmak 1, \\
Teması & Offke(lenmek) 4, Öfke sonucunda ortaya çıkan tepki \\
& 1, Seviyesiz bir insan 1,
\end{tabular}

Bağımlılık
Yaratan
Alışkanlık
Teması

Temas

\begin{tabular}{|c|c|c|c|}
\hline $\begin{array}{l}\text { Canlılığın } \\
\text { Yitirilmesi } \\
\text { Teması }\end{array}$ & 7 & $\begin{array}{l}\text { Çürümüs bir çiçek 1, Dalları kopuk bir ă̆aç 1, Kuru } \\
\text { bir ağaç 2, Orman yangını 1, Solmuş bir gül 1, } \\
\text { Sonbaharda yapraklarl dökülen ağaç 1, }\end{array}$ & 6 \\
\hline $\begin{array}{l}\text { Doğal Afet } \\
\text { Teması }\end{array}$ & 13 & $\begin{array}{l}\text { Deprem 3, Doğal afet 1, Fırtına 2, Felaket 3, } \\
\text { Okyanusun kızışması 1, Şimşek 2, Yıldırım 1, }\end{array}$ & 7 \\
\hline $\begin{array}{l}\text { Kara Delik } \\
\text { Teması }\end{array}$ & 16 & $\begin{array}{l}\text { Cehennem 4, Dehşettir 1, Gece karanlık bir ormanda } \\
\text { kalmak 1, Güvensizlik 1, İnsanı karanlığa götüren } \\
\text { şey 1, Kâbus 2, Karanlık bir dünyanın içindeymiş } \\
\text { gibidir 1, Karanlık bir gece 1, Karanlıkta kalmış bir } \\
\text { ışık parçası 1, Ölümle hayat arasındaki çizgi 1, } \\
\text { Yalnız insan 1, Üzmek 1, }\end{array}$ & 12 \\
\hline $\begin{array}{l}\text { Kayboluş } \\
\text { Teması }\end{array}$ & 13 & $\begin{array}{l}\text { Bir tür çöküş 1, Kalp atışının durması 1, Geri kalmış } \\
\text { toplum 1, Ölüm 6, Çaresizlik 1, Depremde evini } \\
\text { kaybetmek 1, Sevgiden mahrum kalmış insan 1, } \\
\text { Zehir 1, }\end{array}$ & 8 \\
\hline Korku Teması & 30 & $\begin{array}{l}\text { Acı 1, Acı bir biber 1, Ağlara takılan mahsur karınca } \\
\text { 1, Canavar 5, Çocukların psikolojisini bozan } \\
\text { uygulama 1, İğne ve bıçak 1, Korku 15, Korku ve } \\
\text { nefret 1, Savaşın bir parçası 1, Silah 1, Tehlike } \\
\text { içinde olmak 1, Ürkütücü bir şey 1, }\end{array}$ & 12 \\
\hline
\end{tabular}

Baskı 2, Birinin başka birine zorla yaptığı tepkiler 1, Bir kimseye kötü davranmak 1, Bir şeye kötü yönde zarar vermek 1, Çevreye verdiğimiz zarar 1 ,

Zor Kullanma Çocukların kötü yaşaması 1, Eziyet 1, Insanı ezip Temas1 20 geçmek 2, Insanlara uygulanan bir tür olay 1,

Karşısındaki kişiye zor kullanmak 1, Kötü

davranmak 2, Savaş 2, Sinırları zorlamak 1, Suçsuz

bir top 1, Yıpranmış kâğı 1, Zorbalık 1,

\begin{tabular}{ll}
\hline Hakaret Teması & Bir kişinin kaba davranması 1, Gürültü 1, Hakaret 1, \\
Kabalık 1, Kalp kırcı sözler 1, Kötü laf 1, Ses 1,
\end{tabular}

Tablo 2 incelendiğinde öğrencilerin büyük çoğunluğu (54) şiddeti saldırgan insan temasında değerlendirirken, 30 öğrenci şiddeti korku temasında, 20 öğrenci zor kullanma temasında, 16 öğrenci kara delik temasında, 13 öğrenci kayboluş temasında, 
13 öğrenci doğal afet temasında, 7 öğrenci canlılığın yitirilmesi temasında, 7 öğrenci hakaret temasında, 3 öğrenci de bağımlılık yaratan alışkanlık temasında değerlendirmiştir. Öğrenci algılarına ilişkin görüşlerin daha çok saldırgan insan, korku ve zor kullanma temalarında toplandığı, bağımlılık yaratan alışkanlık temasına ilişkin görüşlerin daha az tekrarlandığı görülmüştür. Öğretmenlere verilen soru formlarından elde edilen metaforlar frekanslarıyla birlikte Tablo 3 'te listelenmiştir.

Tablo 3

Öğretmenler Tarafindan İleri Sürülen Metaforların Temalara Göre Dă̆ılımı

\begin{tabular}{|c|c|c|c|}
\hline $\begin{array}{l}\text { Temalar } \\
(n=9)\end{array}$ & $f$ & $\begin{array}{l}\text { Metaforlar } \\
\qquad(n=45)\end{array}$ & $f$ \\
\hline $\begin{array}{l}\text { Saldırgan İnsan } \\
\text { Teması }\end{array}$ & 8 & $\begin{array}{l}\text { Acizlik 3, Ayna 1, İçimizdeki öfkenin dışa yansıması 1, } \\
\text { Insanlıktan çıkmak 1, Olumsuzluklara karşı tepki 1, } \\
\text { Sorumsuz bir davranış 1, }\end{array}$ & 6 \\
\hline $\begin{array}{l}\text { Bağımlılık } \\
\text { Yaratan } \\
\text { Alışkanlık } \\
\text { Teması }\end{array}$ & 7 & $\begin{array}{l}\text { Alkol 1, Bulaşıcı hastalık 2, Eroin 1, Kötü } \\
\text { alışkanlıklarımız 1, Sigara 1, Su, yemek 1, }\end{array}$ & 6 \\
\hline $\begin{array}{l}\text { Canlılığın } \\
\text { Yitirilmesi } \\
\text { Teması }\end{array}$ & 4 & $\begin{array}{l}\text { Bir gülü ayakla çiğnemek 1, Daha yeni çiçek açmış } \\
\text { fidanın koparılması 1, Hastalık 1, Susuzluk 1, }\end{array}$ & 4 \\
\hline $\begin{array}{l}\text { Doğal Afet } \\
\text { Teması }\end{array}$ & 8 & $\begin{array}{l}\text { Atom bombası 1, Deprem 2, Felaket 1, Fırtına 1, Gök } \\
\text { gürültüsü 1, Sel suları 1, Seti yıkılan bir baraj 1, } \\
\text { Volkan 1, }\end{array}$ & 9 \\
\hline $\begin{array}{l}\text { Kara Delik } \\
\text { Temas1 }\end{array}$ & 4 & $\begin{array}{l}\text { Çocuğun kâbus görmesi 1, Karanlık 1, Labirent 1, } \\
\text { Çaresizliğin öteki adı 1, }\end{array}$ & 4 \\
\hline $\begin{array}{l}\text { Kayboluş } \\
\text { Teması }\end{array}$ & 8 & $\begin{array}{l}\text { Ateş 3, Çaresizlik 1, Eğitimde etkisiz bir eleman 1, } \\
\text { Gecekonduyu yılkmak 1, Med-Cezir 1, Saman alevi 1, }\end{array}$ & 6 \\
\hline Korku Teması & 7 & $\begin{array}{l}\text { Canavar 2, Korku 1, Korku ve acı 1, Korku filmi 1, } \\
\text { Vahşet 1, Vahşi yaratık 1, }\end{array}$ & 6 \\
\hline $\begin{array}{l}\text { Zor Kullanma } \\
\text { Teması }\end{array}$ & 2 & Fiziksel bir tepki 1, Insan haklarını ezmek 1, & 2 \\
\hline Hakaret Teması & 1 & Aşağllama 1, & 1 \\
\hline
\end{tabular}

Tablo 3 incelendiğinde araştırmaya katılan öğretmenlerden şiddeti saldırgan insan davranışı, doğal afet ve kayboluş temasında değerlendiren görüşlerin frekansı 8 iken korku ve bağımlılık yaratan alışkanlık temasında 7, canlılığın yitirilmesi ve kara delik temasında 4'er öğretmen görüşü bulunmaktadır. Yine zor kullanma temasında 2 öğretmen görüşü varken hakaret temasında 1 öğretmen görüşü bulunmaktadır. Öğretmen algılarına ilişkin görüşlerin daha çok saldırgan insan, doğal afet ve kayboluş temalarında toplandığı, zor kullanma ve hakaret temasına ilişkin görüşlerin daha az tekrarlandığ1 görülmüştür. Saldırgan insan temasındaki metaforlar ve frekans dağılımları Tablo 4'te yer almaktadır. 
Tablo 4

Saldırgan İnsan Temasındaki Metaforlar ve Frekans Dă̆ılımları

\begin{tabular}{lccc}
\hline & \multicolumn{2}{c}{ Öğrenci Görüşleri } & $f$ \\
\hline Metafor & $f$ & Metafor & 1 \\
\hline Azarlamak & 1 & İşkence & 2 \\
Bağırıp çağırmak & 3 & Kavga & 2 \\
Bilinçsiz insanın yöntemi & 1 & Kızgın bir insan & 1 \\
Birini dövmek hayata & 1 & Kızmak & 4 \\
küstürmek & & Öfke(lenmek) & 1 \\
Dayak & 33 & Öfke sonucunda ortaya & 1 \\
İnsanın elinden çıkan kaza & 1 & çıkan tepki & \\
İnsanları cezalandırmak & 1 & Seviyesiz bir insan & 1 \\
İnsanlara zarar vermek & 1 & & 1 \\
\hline & Öğretmen Görüşleri & 1 \\
\hline Acizlik & 3 & İnsanlıktan çıkmak & \\
Ayna & 1 & Olumsuzluklara karşı tepki & \\
İçimizdeki öfkenin dışa & 1 & Sorumsuz bir davranış & \\
yansıması & & & \\
\hline
\end{tabular}

$\mathrm{Bu}$ kategoride yer alan görüşlere göre 54 öğrenci ve 8 öğretmen şiddeti "saldırgan insan davranışı" olarak tanımlamıştır. Bu temaya görüş bildiren öğrencilerin şiddeti en çok dayağa benzettikleri görülmüştür. Öğretmenler ise şiddeti daha çok acizliğe benzetmişlerdir. Öğrenci ve öğretmenlerin bu temayı temsil eden metaforlara ilişkin tanımlamalarından bazıları aşağıda yer almaktadır.

Sevgiden mahrum kalmış insan gibidir. Çünkü hayatta her şeyden önce sevgi ve mutluluk gelir. Sevgi ve mutluluktan mahrum bir insan sonsuzluğun karanlığına hapsedilmiş gibidir. (Öğrenci)

Acizliktir. Kendine güvenmeyen ve aciz insanların uyguladığı yaptırımdır. (Öğretmen)

Ayna gibidir. Sen ona uygularsın, o da vakti gelince yansıma gibi başkasına uygular. (Öğretmen)

Öğrenci ve öğretmen görüşlerine göre bağımlılık yaratan alışkanlık temasındaki metaforlar ve frekans dağılımları Tablo 5 'te gösterilmiştir.

Tablo 5

Bă̆ımlılık Yaratan Alışkanlık Temasındaki Metaforlar ve Frekans Dă̆llımları

\begin{tabular}{lccc}
\hline & \multicolumn{2}{c}{ Öğrenci Görüşleri } & $f$ \\
\hline Metafor & $f$ & Metafor & 1 \\
\hline Hayatın parçası & 1 & Şiddetten zevk alan & \\
Sigara & 1 & & 1 \\
\hline & Öğretmen Görüşleri & 1 \\
Alkol & 1 & Kötü alışkanlıklarımız & 1 \\
Bulaşıcı hastalık & 2 & Sigara & Su, yemek
\end{tabular}


İlgili görüşler incelendiğinde araştırmaya katılan 7 öğretmen ve 3 öğrencinin bu temaya uygun görüş bildirdikleri görülmüştür. Bu temaya ilişkin olarak, öğrencilerin şiddeti hayatlarının bir parçası olarak gördügü, şiddetten zevk aldıkları söylenebilir. Öğretmenler ise bu tema içinde, şiddeti daha çok bulaşıcı hastalığa benzetmişlerdir. Bağımlılık yaratan alışkanlık olarak belirtilen bu temadaki metaforlara ilişkin öğrenci ve öğretmen tanımlamaları şu şekildedir.

Hayatın parçasıdır. Çünkü hiç kimse şiddet görmedim diyemez. (Öğrenci)

Alkol gibidir. Uygulandıkça alışkanlık yapar. (Öğretmen)

Canlılığın yitirilmesi temasındaki metaforlar ve frekans dağılımlarına ilişkin öğrenci ve öğretmen görüşleri Tablo 6'da yer almaktadır.

Tablo 6

Canlılı̆̆ın Yitirilmesi Temasındaki Metaforlar ve Frekans Dă̆ılımları

\begin{tabular}{lllc}
\hline & \multicolumn{2}{c}{ Öğrenci Görüşleri } & $f$ \\
\hline Metafor & $f$ & Metafor & 1 \\
\hline Çürümüş̧ bir çiçek & 1 & Orman yangını & 1 \\
Dalları kopuk bir ağaç & 1 & Solmuş bir gül & 1 \\
Kuru bir ağaç & 2 & Sonbaharda yaprakları dökülen ağaç & 1 \\
\hline & Öğretmen Görüşleri & 1 \\
Bir gülü ayakla çiğnemek & 1 & Hastalık & \\
Daha yeni çiçek açmış fidanın & 1 & Susuzluk & \\
koparılması & &
\end{tabular}

$\mathrm{Bu}$ temada yer alan katılımcı ifadeleri incelendiğinde, 7 öğrenci ve 4 öğretmen "canlılığın yitirilmesi” temasında görüş bildirmişlerdir. Bu temaya ilişkin görüşler aşağıda yer almaktadır.

Çürümüş bir çiçek gibidir. Şiddet gören bir insan çürümüş bir çiçeğe benzer. (Öğrenci)

Daha yeni çiçek açmış fidanın koparılması gibidir. Şiddet özellikle küçük yaş gruplarında özenle oluşturulmuş bir altyapının, köküne dinamit konulmuş bir bina gibi saniyeler içinde yerle bir olması demektir. (Öğretmen)

Doğal afet temasındaki metaforlar ve frekans dağılımlarına ilişkin öğrenci ve öğretmen görüssleri Tablo 7'de yer almaktadır.

Tablo 7

Doğal Afet Temasındaki Metaforlar ve Frekans Dağılımları

\begin{tabular}{llll}
\hline & \multicolumn{2}{c}{ Öğrenci Görüşleri } & $f$ \\
\hline Metafor & $f$ & Metafor & 1 \\
\hline Deprem & 3 & Okyanusun kızışması & 2 \\
Doğal afet & 1 & Şimşek & 1 \\
Fırtına & 2 & Yıldırım &
\end{tabular}




\begin{tabular}{|c|c|c|c|}
\hline \multicolumn{4}{|c|}{ Öğretmen Görüşleri } \\
\hline Atom bombas 1 & 1 & Gök gürültüsü & 1 \\
\hline Deprem & 2 & Sel suları & 1 \\
\hline Felaket & 1 & Seti yıkılan bir baraj & 1 \\
\hline Firtına & 1 & Volkan & 1 \\
\hline
\end{tabular}

Araştırmaya katılan 13 öğrenci ve 8 öğretmen şiddeti “doğal afet" temasına ilişkin değerlendirmiştir. Öğretmen ve öğrenciler şiddeti insanın en çaresiz kaldı ̆̆ deprem, fırtına, şimşek, gök gürültüsü, sel ve volkana benzetmişlerdir. Bu temaya uygun öğretmen ve öğrenci görüşleri aşağıdaki gibidir.

Şimşek gibidir. Çünkü vurduğu yeri devirir, yakar, yıkar, kül eder. (Öğrenci)

Seti yıkılan bir baraj gibidir. Önüne gelen her şeyi yıkıp götürür. Şiddet de çevresinde canlı ve cansız olan her şeye kontrolsüz bir şekilde zarar verir. Kontrol altına alınması zordur. (Öğretmen)

Kara delik temasındaki metaforlar ve frekans dağılımlarına ilişkin öğrenci ve öğretmen görüssleri Tablo 8'de yer almaktadır.

Tablo 8

Kara Delik Temasındaki Metaforlar ve Frekans Dă̆llımları

\begin{tabular}{llll}
\hline & \multicolumn{2}{l}{ Öğrenci Görüşleri } & $f$ \\
\hline Metafor & $f$ & Metafor & 1 \\
\hline Cehennem & 4 & Karanlık bir gece & 1 \\
Dehşet & 1 & Karanlıkta kalmış bir 1şık & 1 \\
Gece karanlık bir ormanda & 1 & parçası & 1 \\
kalmak & & Ölümle hayat arasındaki çizgi & 1 \\
Güvensizlik & 1 & Yalnız insan & 1 \\
İnsanı karanlığa götüren şey & 1 & Üzmek & \\
Kâbus & 2 & & \\
Karanlık bir dünyanın içinde & 1 & & \\
olmak & & &
\end{tabular}

\begin{tabular}{lccc}
\hline & Öğretmen Görüşleri & \\
\hline Çaresizliğin öteki adı & 1 & Karanlık & 1 \\
Çocuğun kâbus görmesi & 1 & Labirent & 1 \\
\hline
\end{tabular}

Tablo 8'e göre araştırmaya katılan 4 öğretmen ve 16 öğrencinin Kara delik temasına uygun görüş bildirdikleri görülmüştür. Öğretmen ve öğrenciler şiddeti cehenneme, kabusa, karanlık bir dünya içinde olmaya benzetmişlerdir. $\mathrm{Bu}$ temaya ilişkin katılımcı görüşlerine aşağıda yer verilmiştir:

Ölümle hayat arasındaki çizgi gibidir. Dayakta ölüm de vardır, yaşam da vardır. (Öğrenci)

Labirent gibidir. Uygulandıkça kişi arsızlaşır, içinden çıkamaz. (Öğretmen)

Kayboluş temasındaki metaforlar ve frekans dağılımlarına ilişkin öğrenci ve öğretmen görüşleri Tablo 9'da yer almaktadır. 
Tablo 9

Kayboluş Temasındaki Metaforlar ve Frekans Dağılımları

\begin{tabular}{lclc}
\hline & \multicolumn{2}{c}{ Öğrenci Görüşleri } & $f$ \\
\hline Metafor & $f$ & Metafor & 1 \\
\hline Bir tür çöküş & 1 & Çaresizlik & 1 \\
Kalp atışının durması & 1 & Depremde evini kaybetmek & 1 \\
Geri kalmış toplum & 1 & Zehir & 1 \\
Ölüm & 6 & & 1 \\
\hline & Öğretmen Görüşleri & 1 \\
\hline Ateş & 3 & Gecekonduyu yıkmak & \\
Çaresizlik & 1 & Med-Cezir & Saman alevi \\
Ĕgitimde etkisiz bir eleman & 1 & & \\
\hline
\end{tabular}

Kayboluş temasına ilişkin 12 öğrenci ve 8 öğretmen görüşü bulunmaktadır. Bu temaya görüş bildiren öğretmenlerin ve öğrencilerin şiddeti, hayatlarında yaşayabilecekleri en kötü olaylar olarak algıladıkları görülmektedir. Öğretmen ve öğrenciler bu temaya ilişkin olarak ölüm gibi, depremde evini kaybetmek gibi benzetmeler yapmıştır. İlgili temaya uygun görüş bildiren katılımcı metaforları aşağıdaki gibidir.

Kalp atışının durması gibidir. Şiddet her an insanı ölüme götürebilir. (Öğrenci)

Med-Cezir gibidir. Güzel, verimli ve huzurlu olan görünüşü birkaç saat içinde çorak, kupkuru ve verimsiz hale getirir. Şiddet tamamen sona ermedikçe şiddete uğrayan kişi için bu gel-git hep var olacaktır. (Öğretmen)

Korku temasındaki metaforlar ve frekans dağılımlarına ilişkin öğrenci ve öğretmen görüşleri Tablo 10'da verilmiştir.

Tablo 10

Korku Temasındaki Metaforlar ve Frekans Dă̆llımları

\begin{tabular}{lccc}
\hline & & Öğrenci Görüşleri & $f$ \\
\hline Metafor & $f$ & Metafor & 1 \\
\hline Acı & 1 & İğne ve bıçak & 15 \\
Acı bir biber & 1 & Korku & 1 \\
Ağlara takılan mahsur & & Korku ve nefret & 1 \\
karınca & 1 & Savaşın bir parçası & 1 \\
Canavar & 5 & Silah & 1 \\
Çocukların & Tehlike içinde olmak & 1 \\
psikolojisini bozan & & Ürkütücü bir şey & \\
uygulama & 1 & & 1 \\
\hline & & Öğretmen Görüşleri & 1 \\
\hline Canavar & 2 & Korku filmi & 1 \\
Korku & 1 & Vahşet & Vahşi yaratık \\
Korku ve acı & 1 & & \\
\hline
\end{tabular}


Bu temada yer alan katılımcı ifadelerine göre; 30 öğrenci ve 7 öğretmen şiddeti "korku teması" içinde değerlendirmişlerdir. Bu temaya görüş bildiren öğretmenler ve öğrenciler şiddeti acı biber gibi, iğne gibi, silah gibi bir korku unsuru olarak değerlendirdiklerini dile getirmişlerdir. İlgili temaya ilişkin katılımcı görüşlerine aşağıda yer verilmiştir:

Ağlara takılan mahsur karınca gibidir. Şiddet gördügümüzde yalnız kalırız ve hiç kimse tarafından fark edilemeyiz. Yardım isteriz fakat sesimizi duyuramayız. (Öğrenci)

İğne ve bıçak gibidir. Çünkü iğne ve bıçak gibi insana batınca kanatır. (Öğrenci)

Korku filmi gibidir. Şiddetin olduğu her yerde her zaman korku ile yaşanır o da kişilerin psikolojisini bozar ve huzursuzluğa yönlendirir. (Öğretmen)

Zor kullanma temasındaki metaforlar ve frekans dağılımlarına ilişkin öğrenci ve öğretmen görüşleri Tablo 11'de yer almaktadır.

Tablo 11

Zor Kullanma Temasındaki Metaforlar ve Frekans Dağılımları

\begin{tabular}{lclc}
\hline & Öğrenci Görüşleri & $f$ \\
\hline Metafor & $f$ & Metafor & 1 \\
\hline Baskı & 2 & İnsanlara uygulanan bir tür olay & 1 \\
Birinin başka birine zorla yaptı̆̆ı tepkiler & 1 & Karşısındaki kişiye zor & \\
Bir kimseye kötü davranmak & 1 & kullanmak & 2 \\
Bir şeye kötü yönde zarar vermek & 1 & Kötü davranmak & 1 \\
Çevreye verdiğimiz zarar & 1 & Savaş & 1 \\
Çocukların kötü yaşaması & 1 & Sinırları zorlamak & 1 \\
Eziyet & 1 & Suçsuz bir top & 1 \\
İnsanı ezip geçmek & 2 & Yıpranmış kâğıt & 1 \\
& & Zorbalık & 1 \\
\hline
\end{tabular}

Öğretmen Görüşleri

\begin{tabular}{lll}
\hline Fiziksel bir tepki & 1 & İnsan haklarını ezmek \\
\hline
\end{tabular}

Araştırmaya katılan 20 öğrenci ve 2 öğretmen şiddeti "zor kullanma" temasına ilişkin değerlendirmiştir. Bu tema içinde öğretmen ve öğrenciler şiddeti baskıya, kötü davranmaya, savaşa benzettikleri görülmüştür. Bu temaya görüş bildiren öğrenciler ve öğretmenler, istemedikleri halde bir şeyleri yapmaya mecbur bırakma davranışını şiddet olarak algılamaktadır. Bu temaya uygun öğretmen ve öğrenci görüşleri aşağıdaki gibidir.

Yıpranmış kâğıt gibidir. Yıpranmış kâğıtta birçok yara, çizgi vardır. Aynı şekilde insanda da yara vardır. (Öğrenci)

İnsan haklarını ezmek gibidir. Her çocuk hayata atılacak bir bireydir. Şiddetle yaklaşıldığında kişiliği o yönde şekillenecektir. (Öğretmen)

Hakaret temasındaki metaforlar ve frekans dağılımlarına ilişkin öğrenci ve öğretmen görüşleri Tablo 12'de yer almaktadır. 
Tablo 12

Hakaret Temasındaki Metaforlar ve Frekans Dağılımları

\begin{tabular}{llll}
\hline & \multicolumn{3}{c}{ Öğrenci Görüşleri } \\
\hline Metafor & $f$ & Metafor & $f$ \\
\hline Gürültü & 1 & Kalp kırcı sözler & 1 \\
Hakaret & 1 & Kötü laf & 1 \\
Kabalık & 1 & Ses & 1 \\
Bir kişinin kaba & 1 & & \\
davranması & & & \\
\hline
\end{tabular}

Öğretmen Görüşleri

Aşağılama

1

Hakaret temasına ilişkin öne sürülen metaforlar incelendiğinde 7 öğrenci ve 1 öğretmen görüşü dikkat çeker. Bu tema içinde yer alan öğretmen ve öğrenci görüşlerinde şiddetin kötü lafa, kabalığa, aşağılamaya benzetildiği görülmüştür. Bu temada yer alan öğretmen ve öğrenci görüşlerinin fiziksel şiddetten ziyade sözel şiddete uygun olduğu söylenebilir. Bu temayı temsil eden katılımcı görüşleri şunlardır:

Ses gibidir. Çünkü şiddet uygulanınca korku dolu sesler çıkar. (Öğrenci)

Aşağılamadır. Onur kırıcıdır. (Öğretmen)

\section{Sonuç ve Tartışma}

Metafor araştırmaları, herhangi bir kavramla ilgili insanların zihinlerinde var olan algıları doğrudan ortaya çıkarması bakımından güçlü araçlardır. Metaforlar aracılığgyla kamuoyunda sıkça tartışılır hale gelen ve hem öğrenciler hem de öğretmenler için tehdit unsuru olan şiddetin öğretmen ve öğrencilerin zihninde oluşturduğu imajın yani şiddet algılarının ortaya konulması, konunun anlaşılmasına ve hazırlanacak müdahale programlarına katkı sağlayacağı noktasında önem taşımaktadır. Kırsal alandaki ortaokullarda, şiddete ilişkin öğretmen ve öğrenci görüşlerinin metaforlar aracılığı ile belirlendiği bu çalışmada, öğretmenlerin ve öğrencilerin şiddeti saldırgan insan, korku, zor kullanma, kara delik, kayboluş, doğal afet, canlılığın yitirilmesi, hakaret ve bağımlılık yaratan alışkanlık temalarında değerlendirdikleri görülmüştür. Öğrenci algılarına ilişkin görüşlerin daha çok saldırgan insan, korku ve zor kullanma temalarında toplandığı, bağımlılık yaratan alışkanlık temasına ilişkin görüşlerin daha az tekrarlandığı sonucuna ulaşılmıştır. Öğretmen algılarına ilişkin görüşlerin ise daha çok saldırgan insan, doğal afet ve kayboluş temalarında toplandığı, zor kullanma ve hakaret temasına ilişkin görüşlerin daha az tekrarlandığı görülmüştür.

Öğrencilerin ve öğretmenlerin şiddeti en çok benzettikleri saldırgan insan temasına görüş bildiren öğrenciler şiddeti en çok dayağa benzetmişlerdir. Özgür, Yörükoğlu ve Baysan Arabacı (2011) lise öğrencilerinin şiddet algılarını belirlemeye yönelik yapmış oldukları çalışmada öğrenciler, şiddeti daha çok dayak ve kavga olarak fiziksel boyutuyla tanımlamışlardır. Ayrıca Gökler'in (2007) ilköğretim öğrencilerinin akran zorbalığına ilişkin algılarını belirlemek amacıyla yaptığı doktora tez çalışmasında, öğrencilerin tekme, tokat, vurma, çarpma türünden fiziksel zorbalıkların daha çok şiddet olarak algılandığı sonucuna ulaşmıştır. Ulaşılan bu sonuçlar araştırmadan elde edilen 
sonuçlarla benzerlik göstermektedir. Öğretmenlerin ise bu temada şiddeti daha çok acizliğe benzettikleri sonucuna ulaşılmıştır. Bağımlılık yaratan alışkanlık temasına ilişkin olarak, öğrencilerin şiddeti hayatlarının bir parçası olarak gördüğü, şiddeti normal ve sıradan bir davranış olarak kabul ettikleri söylenebilir. Öğretmenlerin ise bu tema içinde, şiddeti daha çok bulaşıcı hastalığa benzettikleri görülmüştür. Canlılığın yitirilmesi temasına görüş bildiren katılımcılar şiddeti insanları en derinden etkileyen, kuru bir ağaç, çürümüş bir çiçek gibi hayatın sonu olarak değerlendirdikleri ortaya çıkmıştır. Doğal afet temasına ilişkin olarak şiddetle karşılaşan öğretmenler ve öğrenciler, insanın en çaresiz kaldığı deprem, firtına, şimşek, gök gürültüsü ve volkan gibi bir yıkım yaşadıklarını belirtmişlerdir. Öğrenciler ve öğretmenler uğradıkları bu yıkımı görüşlerinde dile getirmişlerdir. Kara delik temasına görüş bildiren öğretmenler ve öğrenciler şiddeti cehenneme, kâbusa, karanlık bir dünya içinde olmaya benzettikleri görülmüştür. Kayboluş temasına ilişkin görüş bildiren öğretmenlerin ve öğrencilerin şiddeti, hayatlarında yaşayabilecekleri en kötü olaylar olarak değerlendirdikleri görülmektedir. Öğretmen ve öğrenciler bu temaya ilişkin olarak ölüm ve depremde evini kaybetmek gibi benzetmeler yapmıştır. Şiddeti korku teması içinde değerlendiren öğretmenler ve öğrenciler şiddeti acı biber gibi, iğne gibi, silah gibi bir korku unsuru olarak değerlendirdiklerini dile getirmişlerdir. Öğretmenlerin ve öğrencilerin bu temaya ilişkin algılarına göre; yaşanan şiddet olayları korkuya neden olmaktadır. Zor kullanma temasına ilişkin görüş bildiren öğrenciler ve öğretmenler, şiddeti baskıya, kötü davranmaya, savaşa benzettikleri görülmüştür. Diğer bir anlatımla bu temaya görüş bildiren öğrenciler ve öğretmenlerin, istemedikleri halde bir şeyleri yapmaya mecbur bırakma davranışını şiddet olarak algıladıkları söylenebilir. Hakaret teması içinde yer alan öğretmen ve öğrenci görüşlerinde şiddetin kötü lafa, kabalığa, aşağılamaya benzetildiği görülmüştür. Bu temada yer alan öğretmen ve öğrenci görüşlerinin fiziksel şiddetten ziyade sözel şiddete uygun olduğu sonucuna ulaşılmıştır. Bu tema ile ilgili olarak; öğretmen ve öğrenci algılarının sözel şiddete uygun olduğu sonucuna ulaşılmıştır. Millî Eğitim Bakanlığı'nın 2008 yılında öğrencilerin şiddet algılarını ölçmeye yönelik olarak hazırladığı raporda da öğrencilerin sözel olarak hoşa gitmeyen davranışları (bağırmak, alay etmek, suçlamak, aşağılayıcı söz söylemek) şiddet olarak algıladıklarını göstermektedir.

Sonuç olarak öğretmen ve öğrenci algılarına göre olumsuz ifadelerle anlatılan şiddet olgusu, sağlıklı nesiller için öğretmenlerin ve öğrencilerin uzak durması gereken bir olgudur. $\mathrm{Bu}$ konu ile ilgili ailelerin ve eğitimcilerin sorumluluklarının farkında olması ve etkili davranış örüntülerine sahip olmaları şiddeti önlemede ve var olan şiddetin etkilerini azaltmada önem taşımaktadır. Yine kırsal alanda yer alan okullarda rehberlik servisinin yaygınlaştırılması, bu okullarda gözlenen şiddet olaylarını önlemede etkili olacağı düşünülmektedir. Unutulmamalıdır ki öğretmenin öğrenciye yönelik yapmış olduğu olumsuz bir davranış öğrencinin eğitim hayatını tümden yok edebilir ya da öğrencinin bir anlık davranışı öğretmenin hayatına mal olabilir. 


\section{Summary}

Purpose and Significance: It is suggested that the violence phenomenon in education institutions has become an alarming issue in recent years in parallel with the increase in visibility level in our country. In recent years, the phenomenon of violence that started in schools disturbs all mankind and leads to thinking, speaking and doing scientific research on violence. The phenomenon of violence, which manifests itself in very different forms, has become a phenomenon that we face frequently in both individual and social dimensions.

Considering that the perceptions of teachers and students significantly affect the quality of education in schools; it is seen that it is important to reveal the perceptions of teachers and students about this concept in order to prevent the violence and to take educational measures. In this respect, it is expected that the results of this research will contribute to prevent and reduce the incidents of violence. In this study, it has been tried to reveal the appearance of violence that has become inevitable in schools in rural areas. For this purpose, the following questions were sought.

1. What are the metaphors of the six, seven and eighth grade students studying in secondary schools and the teachers who work in these schools?

2. Which conceptual categories do the six, seven and eighth grade students studying in secondary schools and the metaphors of the teachers working in these schools gather about violence?

3. What is the frequency distribution of metaphors proposed by students and teachers?

Methods: In this research, phenomenology evaluated within the qualitative paradigm is shaped by phenomenology by the pattern. The study population consists of secondary schools located in Palu district of Elazı̆g province. The sample of the study consists of five randomly selected middle schools from Palu district. Three of these schools are located in the district center and two of them are village schools. Research data were collected through metaphors. In this direction, to reveal the perceptions of students and teachers about the phenomenon of violence, all participants were asked to complete the sentence "Violence........ like this. Because.........". The participants were asked to complete the questionnaire and the students were asked to complete the questionnaire. This form, which was completed by all participants, was accepted as the main data source of the research. Teachers and students based on the analysis of data obtained from the opinions of qualitative research used in the analysis of "content analysis" method is used. Each of the questionnaires created for teachers and students was transferred to the electronic environment by giving a number and the responses were analyzed in the statistical data analysis program. In order to test the reliability of the research, it was presented to the expert opinion to determine whether the 216 metaphors obtained from the teachers and students were suitable for the theme. For this purpose, the theme list and metaphors created by the expert and the theme list and metaphors created by the researcher were matched.

Results: Metaphor research is a powerful tool in terms of directly revealing the perceptions that exist in people's minds about any concept. It is important at this point 
that the concept of violence, which is frequently discussed in the public through metaphors and which is the threat of violence for both students and teachers, creates the perception of violence in the minds of teachers and students. In this study in which teachers and students' opinions on violence in rural secondary schools were determined by metaphors, it was observed that teachers and students evaluated violence against aggressive people, fear, hard use, black hole, disappearance, natural disaster, loss of life, insecurity and addictive habit themes. It has been observed that views on student perceptions are more frequently gathered in aggressive people, fear and hard use themes, and opinions about addictive habit theme are less repetitive. The views on the perceptions of teachers were more frequently encountered in the subjects of aggressive, natural, and disappeared, and the views on the theme of difficult use and insult were less repetitive.

Discussion and Conclusions: Being aware of the responsibilities of families and educators and having effective behavioral patterns are important in preventing violence and reducing the effects of existing violence. It is thought that the guidance service in schools in rural areas will be more effective in preventing violence in these schools. It should not be forgotten that a negative behavior of the teacher towards the student may destroy the student's educational life completely, or the student's momentary behavior may cost the teacher's life. 


\section{Kaynakça}

Arnett, R. C. (1999). Metaphorical guidance: administration as building and renovation. Journal of Educational Administration, 37(1), 80-89.

Ayan, S. (2007). Aile içinde şiddete uğrayan çocukların saldırganlık eğilimleri. Anadolu Psikiyatri Dergisi, 8, 206-214.

Bakıcı, Y. (2012). Kültür ve medeniyet şehri Palu. Elazığ: Güntek Matbaa.

Bandura, A. (1978). Social learning theory of aggression. Journal of Communication, 28(3), 12-29.

Cerit, Y. (2008). Öğrenci, öğretmen ve yöneticilerin müdür kavramı ile ilgili metaforlara ilişkin görüşleri. Eğitim ve Bilim, 33(147), 3-13.

Clarken, R. H. (1997). Five metaphors for educators. (ERIC Document Reproduction Service No. ED407408).

Cornelissen, J. P., Oswick, C., Christensen, L. T., \& Phillips, N. (2008). Metaphor in organizational research: context, modalities and implications for research introduction. Organization Studies, 29(7), 8-22.

Çetiner, G. Ş. (2006). Aile içi şiddet yaşayan kadınlarda cinsel sorunlar ve intihar olasılı̆̆l (Yayınlanmamış Yüksek Lisans Tezi). Ankara Üniversitesi, Ankara.

Çınkır, Ş. (2006, Mart). Okullarda zorbalık: türleri, etkileri ve önleme stratejileri. I. Şiddet ve Okul Sempozyumu, MEB ve Unicef İşbirliği, İstanbul.

Gamsız Bilgin, N., Toros, F., Çamdeviren, H. \& Şaşmaz, T. (2004). Okullarda fiziksel ve sözel şiddete maruz kalan çocukların sosyodemografik özellikleri: prevalans çalışması. Türkiye Klinikleri Adli Tıp Dergisi, 1, 25-30.

Girmen, P. (2007). İlköğretim öğrencilerinin konuşma yazma sürecinde metaforlardan yararlanma durumları (Yayınlanmamış Doktora Tezi). Anadolu Üniversitesi, Eskiş̧ehir.

Gökler, R. (2007). Illköğretim öğrencilerinde akran zorbalı̆̆ının bazı değişsenler açısından incelenmesi (Yayınlanmış Doktora Tezi). Ankara Üniversitesi, Ankara.

Işık, H. (2006, Mart). Çocuk suçluluğu ve okullar ile ilişkisi. I. Şiddet ve Okul Sempozyumu, MEB ve Unicef İşbirliği, İstanbul.

Kale, N. (2004). Etik sorunsallar ve eğitim. Ankara: Seçkin Yayınevi.

Kartal, H. (2009). Öğretmen adaylarının uygulama okullarındaki zorbalıkla ilgili değerlendirmeleri. Gazi Eğitim Fakültesi Dergisi, 29(1), 141-172.

Kızmaz, Z. (2006). Okullardaki şiddet davranışının kaynakları üzerine kuramsal bir yaklaşım. C. ̈̈. Sosyal Bilimler Dergisi, 1(30), 47-70.

Küçükturan, G. \& Akbaba Altun, S. (2006, Mart). Okul öncesi dönem çocuklarına uygulanan şiddetin değerlendirilmesi, I. Şiddet ve Okul Sempozyumu, MEB ve Unicef İşbirliği, İstanbul.

Lopez, J.J. (2007). Notes on metaphors, notes as metaphors: the genome as musical spectacle. Science Communication, 29(7), 1-29.

MEB, Eğitimi Araştırma ve Geliştirme Dairesi Başkanlığı. (2008). Öğrencilerin şiddet algısı. Ankara, https://www.meb.gov.tr/earged/earged/siddet_algisi.pdf 17.11.2018 tarihinde indirilmiştir. 
Mertoğlu, M. (2008). İstanbul'da yoğun göç alan bölgelerdeki ilköğretim okullarında görevli ögretmen ve yöneticilere verilen eğitimin, şiddet algllarına ve tutumlarına etkisinin incelenmesi (Yayımlanmamış Doktora Tezi). İstanbul Üniversitesi, İstanbul.

Miles, M.B. \& Huberman, A.M. (1994). Qualitative data analysis. London: Sage Publication

Mutlu, E. (1997). Televizyon, çocuklar ve şiddet. İletişim Fakültesi Dergisi, 4, 41-75.

Olweus, D. (1999). Norway. In Smith, P.K., Morita, Y., Junger-Tas, J., Olweus, D., Catalano, R., \& Slee, P. (Eds). The nature of school bullying: a cross-national perspective (pp. 28-48). London: Routledge.

Özgür, G., Yörükoğlu, G. \& Baysan Arabac1, L. (2011). Lise öğrencilerinin şiddet algıları, şiddet eğilim düzeyleri ve etkileyen faktörler. Journal of Psychiatric Nursing, 2(2), 53-60.

Özönder, C. (2005). İlköğretim okullarının 7 ve 8. sinıflarında okuyan öğrencilerin "okulda şiddet" ve "taciz" kavramlarına ilişkin kavramsallaştırmaları. http://www.turkegitimsen.org.tr/lib_basili/72.pdf adresinden 17.11.2017 tarihinde indirilmiştir.

Saban, A., Koçbekir, B. N. \& Saban, A. (2006). Öğretmen adaylarının öğretmen kavramına ilişkin algılarının metafor analizi yoluyla incelenmesi, Kuram ve Uygulamada Ë̆itim Bilimleri, 6(2), 461-522.

Taktak, N. (2007). Illköğretim kurumlarında "şiddet” (6., 7. ve 8. sinıf ögrencileri üzerine bir araştırma) (Yayımlanmamış Yüksek Lisans Tezi). Beykent Üniversitesi, İstanbul.

Terzi, Ş. (2007). Okullarda yaşanan şiddet önleyici bir yaklaşım: kendini toparlama gücü. Aile ve Toplum Dergisi, 12(3), 73-82.

Totan, T. (2007). Okulda zorbalığ önlemede eğitimcilere ve ebeveynlere öneriler. $A \dot{I} B \ddot{U}$ Ĕ̈itim Fakültesi Dergisi, 7(2), 190-202.

Usta, A. (2009). Etnik şiddet olgusu üzerine sosyo-psikolojik bir değerlendirme. Polis Bilimleri Dergisi, 11(2), 87-106.

Uysal, A. (2003). Şiddet karşıtı programlı eğitimin öğrencilerin çatışma çözümleri, şiddet eğilimleri ve davranışlarına yansıması (Yayımlanmamış Doktora Tezi), Ege Üniversitesi, İzmir.

Yalçın, M., \& Erginer, A. (2012). İlköğretim okullarında okul müdürüne ilişkin metaforik algilar. Journal of Teacher Education and Educators, 1(2), 229-256.

Yatmaz, A. (2009). Orta dereceli mesleki ve teknik ĕ̆itim okullarında öğrenci algılarına göre, öğrencilerin şiddet ĕgilimlerinin nedenleri: nitel bir araştırma (Yayımlanmamış Yüksek Lisans Tezi). Yeditepe Üniversitesi, İstanbul.

Yıldırım, A. \& Şimşek, H. (2011). Sosyal bilimlerde nitel araştırma yöntemleri. Ankara: Seçkin Yayıncılık. 